\title{
An Exploration into the Barriers and Facilitators Experienced by University Graduates with Disabilities Requiring Personal Assistance Services
}

\author{
Norma J. Stumbo, Bradley N. Hedrick, Courtney Weisman, and Jay K. Martin
}

\begin{abstract}
The purpose of this preliminary study was to explore the residual barriers and facilitators for a selected group of individuals with severe physical disabilities who had been afforded a comprehensive set of strategies and services aimed at meeting their basic personal as well as academic needs. Their perceptions of both barriers and facilitators, experienced while in school and post-graduation, were the focus of this qualitative research study. Due to the funding source, differences between individuals who majored in science, technology, engineering, and mathematics (STEM) and non-STEM fields were also explored. Personal interviews were conducted with a stratified random sample of 13 individuals with severe physical disabilities (IWSPD) that necessitated personal assistance and had lived at Beckwith Hall and its forerunners at the University of Illinois. Frequent educational barriers included social isolation with fewer attitudinal, programmatic, financial, or health barriers. Career barriers included more instances of social/communication and architectural/environmental barriers. Education facilitators included the disability support staff on campus; living in Beckwith Hall; state and university financial assistance; positive attitudes of faculty, staff, and fellow students; and accessibility of campus. Career facilitators included work supervisors and colleagues, with few other facilitators mentioned. STEM students were more likely to report (a) campus inaccessibility as an educational barrier, (b) career barriers of access, negative attitudes, financial expenses, and health problems, (c) disability support staff and Beckwith Hall as educational facilitators, and (d) a wider variety and frequency of career facilitators. This study provides initial yet valuable insights into the lived experience of IWSPD as they progress through postsecondary education and transition to the world of work. Significant educational supports are needed to ensure the success of IWSPD.
\end{abstract}

Key words: Education, employment, science, technology, engineering, mathematics, severe physical disabilities, barriers, facilitators, personal interviews, qualitative analysis

\section{INTRODUCTION}

Living with a disability in the United States often translates into lower rates of attendance at and graduation from postsecondary degree programs and lower rates of employment (Dowrick, Anderson, Heyer, \& Acosta, 2005; Stodden \& Dowrick, 1999; Stodden, Whelley, Chang, \& Harding, 2001). This is especially true for individuals with severe physical disabilities who present multi-faceted, enduring, and financially and logistically complex challenges to university systems (Steinmetz, 2006). While these facts are known and reiterated in many studies, the reasons behind these statistics are unclear. Research that begins to explain the levers and mechanisms of reducing barriers and improving facilitators to postsecondary education and careers for individuals with severe disabilities needs to be conducted.

This exploratory study examines, from the perspective of alumni with a severe physical disability who experienced a comprehensive set of strategies and services aimed at reducing or eliminating the impact of personal and academic barriers to postsecondary edu- 
cation and careers. Their perceptions of both barriers and facilitators, while in school and after they graduated, were queried through personal interviews. Due to the funding source, differences between individuals who majored in science, technology, engineering, and mathematics (STEM) and non-STEM fields were also explored.

\section{Disability in America}

Persons with disabilities are a rapidly growing segment of the US and world populations, and this trend is not expected to curtail any time soon. Almost 50 million people $(19.3 \%)$ in the US have some level of disability (Waldrop \& Stern, 2003). This means one in every five individuals reports some type of disability, with one in 10 reporting the existence of a severe disability (United States Bureau of the Census [USBC], 1997) and almost one in 10 reporting more than one disability (Waldrop \& Stern).

Severe physical disability has been defined in a number of ways, from a social construct (Agree \& Freedman, 2003) to difficulty with task accomplishment or activities of daily living (ADLs) and instrumental activities of daily living (IADLs) (Desai, Lentzner, \& Weeks, 2001; Guralnik, 2006; Kennedy, LaPlante, \& Kaye, 1997; Kohler et al. 2005; Verbrugge, Yang, \& Juarez, 2004). In most of these latter definitions, severe physical disability is characterized by functional limitations to the extent that the individual is unable to perform ADLs and IADLs on his or her own and utilizes personal/human assistance (PA) to accomplish those tasks (Hoenig, Taylor, \& Sloan, 2003; Kaye, Chapman, Newcomer, \& Harrington, 2006; LaPlante, Kaye, Kang, \& Harrington, 2004). Kennedy et al. (p. 1) noted that "people with
ADL limitations, and in particular those needing assistance, are considered to have fairly severe disabilities.” Guralnik (p. 162) more specifically defined severe physical disability as when "the individual needs help with three or more of the six ADLs (eating, dressing, bathing, transferring, using the toilet, and walking across a small room)." This definition of severe physical disability, with the emphasis on the utilization of personal assistance, is generally supported throughout the disability and health care literature (cf. Diab \& Johnston, 2004; Jans \& Stoddard, 1999; Philip, Armstrong, Coyle, Chadwick, \& Machado, 1998).

\section{College Enrollment and Persistence}

College enrollment for individuals with disabilities in the US has been reported to be 50 percent lower for people with than people without disabilities (Dowrick et al., 2005; Stodden et al., 2001). Stodden et al. (p. 189) determined that the "proportion of first-time, full-time students with disabilities tripled between 1978 and 1994 from 2.6 to 9.2 percent. By 1998, the full range of students with disabilities (i.e. part-time students and students enrolled in graduate programs) had risen to 10.5 percent of the postsecondary student population."

However, mere "attendance on campus does not equate to earning a degree" for many individuals with disabilities (Belch, 2004, p. $5)$, that is, attendance by individuals with disabilities does not automatically translate to their persistence and graduation. While one study suggested that only 12 percent of all individuals with disabilities entering college actually graduated (Belch), Stodden et al. (2001) quoted the National Center for Educational Statistics' (NCES) 1999 report 
(Horn \& Berktold, 1999) that found, five years after launching their postsecondary program 41 percent of students with disabilities reported they had earned the intended degree or credential, with an additional 12 percent remaining enrolled in their course of study. A different study reported that slightly over 43 percent of individuals without disabilities completed a college degree, compared with 32.5 percent of individuals with nonsevere disabilities, and 21.9 percent of individuals with severe disabilities (Steinmetz, 2006). In all instances, persistence rates for individuals with disabilities do not compare favorably, on average, with other student groups.

The data demonstrate that compared to their nondisabled peers, individuals with disabilities experience far lower rates of high school graduation (National Center for the Study of Postsecondary Education Supports [NCSPES], 2000; National Science Foundation [NSF], 2004; Parker, Shaw, \& McGuire, 2003; Schutz, 2002; Steinmetz, 2006; United States Department of Education, 2005a, 2005b) and postsecondary graduation (NCSPES; National Organization on Disability/Harris, 2004). These latter two statistics reflect "the huge cost of failure to support people with disabilities in postsecondary education programs" (Stodden \& Dowrick, 1999, p. 20) which undoubtedly corresponds to lower rates of full-time, wellpaid employment.

After an extensive search of over 30 library databases, no research could be located on the specific experiences of individuals with severe physical disabilities with regard to postsecondary education. The most similar study, conducted in Sweden, concerned the environment-person fit of individuals with severe physical disabilities in "one of four specially adapted upper secondary schools in Sweden. These schools are accessible for wheelchairs users and the students who attend them are guaranteed adapted schedules within the national upper secondary program" (Hemmingsson \& Borell, 2000, p. 164). Personal assistance services, housing, and a choice of integrated or segregated classes are available. In comparing whether needs were or were not accommodated within the environment, they found that, of eleven areas such as writing, field trips, and speaking, that the most accommodated area was sport, art, and music, with the least accommodated areas being reading and remembering things. The authors reported that the "insufficient student-environment fit in the areas of reading, remembering and speaking, was especially disquieting" ( $p$. 169) as these skills are foundational to further learning, and noted that individual, general, and group accommodations needed to be improved for this group of Swedish students in order to further their education and expand their potential career fields.

\section{Science, Technology, Engineering, and Mathematics (STEM) Education and Careers}

Similar to education, people with disabilities generally experience more barriers to adequate employment than individuals without disabilities (Stodden \& Dowrick, 1999). The National Science Foundation, the funding source for this project, is especially interested in increasing the quality and quantity of individuals with disabilities in science, technology, engineering, and mathematics (STEM) fields. These fields are demanding and preparation frequently entails a number of hurdles for individuals with disabilities that, in turn, reportedly result in lower engagement in STEM fields. Burgstahler 
(1994) noted three main factors for this under-representation: (a) lack of preparation of students with disabilities, (b) lack of access to facilities, programs, and equipment, and (c) lack of acceptance by educators, employers, and co-workers. In terms of lack of adequate preparation, even though there have been significant efforts put into elementary and secondary science education efforts aimed at inclusion of students with disabilities, professionals have failed to develop and validate comprehensive instructional programs that are meeting these individuals' needs (Cawley, Hayden, Cade, \& Baker-Kroczynski, 2002). Even in these early grades, students with disabilities may be subtly discouraged from interest and competence in STEM classes (Milsom, 2006).

The latter two reasons identified by Burgstahler (1994) are closely related. Rao (2004) reported on a number of studies that found that university faculty from the "soft sciences' (e.g., education) had more positive attitudes toward students with disabilities than faculty from the 'hard sciences' (e.g., chemistry, mathematics, physics, and engineering). Weisgerber (1994) remarked that "doing science" was not as difficult as was dealing with the negative attitudes and inflexibility of professors. Ironically, he also noted that these same STEM professors have an overwhelming capacity to seek creative solutions to the classroom and laboratory barriers experienced by students with disabilities.

Similarly, the National Science Foundation (2004) reported that more students with disabilities are enrolled in business, education, health, humanities, and the social sciences than 'hard science' majors such as computer science, engineering, mathematics, and physical sciences. Indeed, NSF data re- vealed that in 2003 only 5.5 percent of employed scientists and engineers had disabilities (NSF, 2004), compared with nearly 20 percent of all Americans who have disabilities. However, given the current shortage of science educators and researchers, the need to encourage all students, including those with disabilities, to consider careers in science is imperative (Lunsford \& Bargerhuff, 2006). Further these researchers stated "Removing barriers that prevent students with disabilities from reaching their full potential as chemists or scientists is vitally important" (Lunsford \& Bargerhuff, p. 407). However, to date, there have been no studies that have attempted to systematically identify (a) the residual barriers and facilitators experienced by students with severe disabilities who have experienced a comprehensive set of postsecondary services, and (b) the differences between individuals entering STEM and non-STEM fields.

\section{Postsecondary Disability Support Ser- vices need to be Evidence-Based and Data-Driven}

One avenue for reducing barriers and enhancing the entry of individuals with disabilities into STEM and other educational programs and employment opportunities is the provision of adequate environmental design-focused and research-based supports and programs (Madaus, 2006). Disabilitysupport services in higher education institutions are vitally important to ensuring student success and future employability and are best designed when they target genuine barriers to student success and reach beyond simple mandatory legal compliance (Paul, 2000). Many postsecondary institutions follow a compliance-driven approach to disa- 
bility services instead of an evidence-based or outcomes approach, and the former falls short of providing students with meaningful interventions aimed at their future success (Collins, Hedrick, \& Stumbo, 2006; Madaus; Paul).

For some individuals with disabilities, unemployment and underemployment are likely to be the result of fragmented approaches to solving disability-related problems (Madaus, 2006). Although disability support services exist in most US higher education institutions to provide services for students with disabilities, these services are frequently insufficient to eliminate or substantially ameliorate the most prominent barriers to the educational participation of students with severe physical disabilities (Bolt, 2004; Madaus; Sanderson, 2001; Stodden \& Conway, 2003; Unger, 1994; Waller et al., 2005).

One of the most pervasive problems in disability-support services in the United States is the lack of data-driven, evidence-based services focused on students' perceptions of barriers (Bolt, 2004; Collins et al., 2006; Gajar, 1998; Madaus, 2006; Parker et al., 2003; Shaw \& Dukes, 2005; Stodden \& Conway, 2003; Stodden \& Dowrick, 1999; Tindal, Health, Hollenbeck, Almond, \& Harris, 1998; Unger, 1994; Waller et al., 2005). Parker, Shaw, and McGuire (2003) asserted that less than one-third of postsecondary disability service providers collected and used program evaluation data to better their programs.

Stodden and Conway (2003) noted that typically postsecondary educational services, supports and programs available to students with disabilities: (a) are fragmented and ineffective; (b) vary extensively across states as well as from campus to campus; (c) are generally not well developed or linked pro- grammatically to instruction; and (d) tend to lean toward advocacy, informational services, or remediation of content rather than support in the areas necessary for independent learning and self-reliance (p. 26). They noted numerous deficiencies in the higher education system, while at the same time, emphasizing that a postsecondary education greatly increases the chances of employment for people with disabilities.

Since the vast majority of postsecondary disability-service providers does not systematically or regularly evaluate their programs, students with disabilities have not benefited consistently from these disability service initiatives and continue to have difficulty obtaining higher education degrees (Bolt, 2004; Sanderson, 2001; Stodden \& Conway, 2003; Unger, 1994; Waller et al., 2005). Given this lack of consistent and needs-based support, students with disabilities may have difficulties overcoming barriers to complete their education (Bolt; MacDonald \& Stratta, 2001; Madaus, 2006; Sanderson). One of the major reasons advocated for conducting research and program evaluation includes gaining factual information needed to make informed decisions about future program development. Research and program evaluation should be targeted to improve as well as prioritize disability-related services so that all students who participate receive maximum benefit (Stodden \& Dowrick, 1999). This is certainly the case for students with severe physical disabilities.

The purpose of this preliminary study was to explore the residual barriers and facilitators for a selected group of individuals with severe physical disabilities who had been afforded a comprehensive set of strategies and services aimed at meeting their basic personal as well as academic needs. Their per- 
ceptions of both barriers and facilitators, experienced while in school and postgraduation, were the focus of this qualitative research study. Due to the funding source, differences between individuals who majored in science, technology, engineering, and mathematics (STEM) and non-STEM fields were also explored.

Prior to discussing the methods used to conduct this study, a brief description of the comprehensive strategies provided to the participants in this research will be provided.

\section{The Illinois Program Model}

In 1959, disability support services personnel at the University of Illinois sought to create a means by which students who needed assistance with activities of daily living could move away from home, reside in the Champaign-Urbana community, attend the University of Illinois, and become better prepared to manage their disabilityrelated needs and move to the locale of the best available employment opportunity after graduation. As a result of that effort, a unique residential program was created between the Division of Disability Resources and Educational Services (DRES) and the Greenbrier Nursing Home of Champaign (personal communication with Professor Emeritus Timothy J. Nugent, October 27, 2006). The students were able to receive the activities of daily living assistance they required from the Greenbrier staff, and, thus, were able to attend classes. In addition, a host of educational services and supports were provided through DRES that were designed to help students with disabilities acquire the knowledge and skills necessary to manage their own personal assistance (PA) needs and facilitate their movement to less restrictive campus or community housing (Collins et al., 2006).

Two years later, in 1961, a private home located on campus about three blocks from DRES was modified and dedicated to serve as a transitional residence for students needing activity of daily living support services. Tanbrier, as the facility came to be known, provided space to accommodate six to eight students with disabilities and a comparable number of live-in personal assistants. Finally, in 1981, Beckwith Residence Hall was opened and a new era in transitional residential support services was born. Since then, Beckwith has served as the primary residence of more than 151 students requiring PA support services (Collins et al., 2006).

Beckwith Hall is a unique University-owned and operated residence hall that offers transitional postsecondary disability resources, training, and services to support the matriculation, retention, graduation, and employment of students who require PA in the performance of activities of daily living. The facility can accommodate up to 22 students who necessitate such assistance and eight to twelve Illinois students without disabilities to assist in the provision of such services. A centralized, single facility approach rather than a multi-facility, decentralized strategy was necessary in the late 1970s because the communal showers and bathroom facilities of mainstream residence halls built in the 1950s and 1960s were ill-suited for students necessitating the aid of PAs of either gender. A centralized residence hall allows for backup PAs while keeping costs reasonable (Collins et al., 2006).

Two important programs within Beckwith Hall are the Transitional Disability Man- 
agement Program (TDMP) for students and the personal assistant training program. During each year of their stay at Beckwith, residents are given the opportunity to participate in the TDMP. Students work with the disability specialist, one-on-one, to determine the areas in which they would like to increase their knowledge and skills. The students and disability specialist then collaborate in the creation of customized individual goals and a work plan for their achievement. The goals may relate to their career aspirations, knowledge of disability laws, ability to effectively advocate for themselves, health and wellness, ability to use a new AT or to more effectively perform or manage the performance of certain activities of daily living, or post-graduate objectives (Collins et al., 2006).

The personal assistance training program consists of two parts, one for the student residents with disabilities and one for the PA employees. Students learn how to hire, train, schedule, manage, evaluate, and fire personal assistants. The employees learn basic skills such as transfers, ulcer prevention, toileting, and dressing. These programs are in addition to a campus-wide accessible bus service, academic support services such as note takers and readers, and health and wellness services (Collins et al., 2006).

In the 2006-07 academic year, 44\% of Beckwith student residents were women and $56 \%$ were men. Of the 18 residents, 17 used power wheelchairs. Seventy-eight percent of the residents had congenital disabilities, such as cerebral palsy or muscular dystrophy, while only $22 \%$ had disabilities resulting from traumatic injuries such as spinal cord injury or brain injury. Undergraduates comprised $83 \%$ of Beckwith students. In terms of retention and graduation, a total of 151 students have resided at Beckwith Hall since the facility opened in 1981 . Of that number, a remarkable $87 \%(\mathrm{n}=109)$ have earned degrees from the University of Illinois. Success following graduation also has been outstanding. Of the 33 former Beckwith residents with severe physical disabilities who graduated between 1994 and 2003, 21 (64\%) obtained professional employment within a year of graduation, and seven $(27 \%)$ enrolled in graduate or professional school within one year of graduation. Thus, less than $9 \%(n=3)$ were unemployed and not enrolled in graduate or professional school within one year of graduation. These data were affirmed by a study performed by the University Office for Planning and Budgeting in 2004 , in which over $58 \%$ of former Beckwith residents who graduated between 1982 and 2002 and responded to the UI Alumni One Year Out Survey reported that they were employed (Collins et al., 2006).

\section{Purpose of the Study}

The purpose of this preliminary study was to identify factors that alumni with severe physical disabilities from the University of Illinois perceived to have hindered or facilitated their educational attainment and/or career achievements in STEM and non-STEM fields. These alumni had lived at Beckwith Hall, Greenbrier, or Tanbrier, and had received additional supports from the DRES office. Given the extent of personal and educational supports provided, the researchers set out to understand how these individuals perceived the barriers and facilitators that were present at the university and in their current employment settings (if any). More specifically, this study attempted to answer the following questions: 
1. What technological, educational, and vocational barriers are perceived to be most detrimental?

2. What technological, educational, and vocational facilitators are perceived to be most beneficial?

3. How do the perceptions of these barriers and facilitators by alumni in STEM fields compare to those in non-STEM fields?

The study was conducted by staff at two universities under the auspices of a grant from Research in Disabilities Education unit at the National Science Foundation. The institutional review boards at both universities approved the study prior to implementation.

\section{METHODS}

\section{Sample}

McMillan and Schumacher (2001) noted that in qualitative studies, it is common that the sample is selected based on their profiles and shared experiences, and be accessible through formal or informal networks. Alumni from the University of Illinois who had lived at Beckwith Hall or its predecessors were selected as they mirrored the profile of persons who had received a comprehensive set of disability management and academic services but who might have encountered additional barriers as well as facilitators to their education and careers.

Staff from DRES, Beckwith Hall, and the University of Illinois Alumni Services Office worked cooperatively to provide a list of all known alumni who had graduated and had lived in Beckwith Hall, Greenbrier, or Tanbrier. Since the focus of this study was individuals with severe physical disabilities, the sample for this study was restricted to persons who had lived at Beckwith Hall or its forerunners.

As per the stratified randomly sampling protocol (MacMillan \& Schumacher, 2001), the total group of 55 eligible individuals listed in the database with adequate addresses then was divided, based on their most recent degree, into STEM and non-STEM majors. (To address the research question, the $\mathrm{Na}$ tional Science Foundation's definition of STEM and non-STEM majors was utilized. For example, STEM majors include engineering, psychology, and computer science; non-STEM majors include business administration, law, and advertising). Since there were only 16 STEM majors remaining on the list, all 16 were identified as potential participants in the STEM sub-sample. An equal number of non-STEM majors was randomly selected. Due to refusals to participate and additional inadequate contact information on the sub-samples, each subsample list was exhausted. The final sample consisted of seven STEM and six -non STEM majors, graduating over the previous 30 years.

While this does not reflect the proportion of STEM vs. non-STEM majors in the original sample of 70 (approximately $70 \%$ nonSTEM), STEM majors were over-sampled so that they may be adequately represented in the qualitative data. In addition, while the research participants' graduation dates spanned a considerable time period, all consenting individuals were utilized so that an adequate sample size could be obtained. 
Vol. 14, No. 1- Winter, 2010/2011

Journal of Science Education for Students with Disabilities

\section{Instrument}

The research team developed the semistructured interview guide used for this preliminary study. The interview guide consisted of five sections: (a) barriers encountered while at school, (b) career barriers encountered since graduation, (c) facilitators encountered while at school, (d) career facilitators encountered since graduation, and (e) demographics. Barriers and facilitators within each of the first four sections included: (a) architectural/ environmental, (b) attitudinal, (c) programmatic/policy, (d) financial, (e) social/communication, and (f) health. These categories were determined through a literature review, expert panel consensus, and a pilot study.

Each barrier or facilitator was queried through one open-ended question, e.g., "Describe any architectural/environmental barriers in relation to your degree program encountered while at school" or "Describe any architectural/environmental facilitators in relation to your degree program encountered while at school." The guide was nine pages in length with four pages covering barriers, four for facilitators, and one for demographics.

\section{Procedure}

The instrument was pilot tested through personal interviews with three individuals with severe physical disabilities and revised minimally. The results from these three interviews were folded into the final sample of 13 in order to maximize variance and representativeness (Depoy \& Gitlin, 1998). The remaining 10 interviews were conducted by telephone, over a period of four months. Potential interviewees were sent an email and/or were telephoned to secure participation, obtain consent, and a schedule a con- venient time. Interviews took approximately thirty to sixty minutes. Extensive but abbreviated notes were taken by the two researchers during the interview with periodic clarification questions (e.g., "So people at work have been a major facilitator for you?"). Immediately following completion of the interview, the researcher expanded the interview notes with additional information, such as direct quotes or summary statements. All handwritten notes were then entered into one electronic file to aid in analysis.

\section{Qualitative Analysis}

Extensive notes from each of the 13 interviews were transferred into an electronic file within the respective sections of education and career barriers, and educational and career facilitators. Each section was then partitioned into STEM and non-STEM columns. Using the constant comparative method (Glaser \& Strauss, 1967), two researchers independently reviewed and scrutinized the data files, for emerging categories and themes, each creating separate syntheses files. The main point of constant comparison is to extract commonalities and differences and to strengthen the external validity or potential generalizability to other populations (Boeije, 2002). The two researchers then discussed data in each section until convergence concerning the main themes was reached (DePoy \& Gitlin, 1998). Boeije labeled this as "fragmenting" and "connecting" and noted that the process helps "accentuate the context and richness of the interview data" (p. 394).

The results of the qualitative analysis were then developed into four tables: (a) educational barriers, (b) career barriers, (c) educational facilitators, and (d) career facilitators. 
These four tables were constructed to answer the first and second research questions for which STEM and non-STEM participants were combined. A fifth table was constructed that highlighted the differences between STEM and non-STEM alumni. These five tables are discussed in the Results section below.

\section{RESULTS}

\section{Sample}

The sample of 13 individuals with severe physical disabilities included eight males and five females. Ages at the time of the interview ranged from 26 to 60 . Graduation decades of their most recent degrees included six individuals in the 2000s, four in the 1990s, two in the 1980s and one in the 1970s. Majors were divided into STEM and non-STEM categories, based on the NSF definition. Seven individuals graduated in STEM majors (e.g., electrical engineering, chemistry, economics, and political science) and six graduated in non-STEM majors (e.g., art, finance, law). Disabilities represented included cerebral palsy, spinal cord injury, and muscular dystrophy and were severe enough for students to seek university housing that afforded personal assistance with ADLs and IADLs. All thirteen individuals were Caucasian, with one individual being part Caucasian and part Asian. Students had spent between 2.5 years and seven years at the university completing one or more degrees. The sample generally reflected individuals who have resided in Beckwith Hall, with the exception of majors - individuals with STEM majors were oversampled due to the research question of per- ceptions of individuals from STEM vs. nonSTEM backgrounds.

\section{Educational and Career Barriers}

The first research question of this study asked: What technological, educational, and vocational barriers are perceived by persons with severe disabilities to be most detrimental? Table 1 contains a summary of the six categories of educational barriers that were used in this study. Physical barriers were present in both building interiors and exteriors, although this was more notable in older buildings. Traveling around campus in a wheelchair could also be a problem due to inaccessible pathways or the sheer size of the campus. While most alumni had not encountered attitudinal barriers, some reported that, on occasion, some students without disabilities and professors displayed negative attitudes. Most alumni also did not report experiencing programmatic or policy barriers, although some reported that policies, such as taking a test in a specified location due to needing a reader or writing assistance, resulted in a sense of their being isolated from their class peers. Few of the study participants reported financial barriers, largely because they received funding for their education from state departments of vocational rehabilitation or from family members. A number of alumni reported social barriers, often resulting from inaccessibility or from negative attitudes (theirs or other students). The majority of students reported no health barriers during their educational experience, although some did mention needing to manage their disability to maintain their health and that faculty and healthcare providers with whom they came into contact needed more information on the effects of a disability on one's health. 
Vol. 14, No. 1- Winter, 2010/2011

Journal of Science Education for Students with Disabilities

\section{Table 1. Educational Barriers for Sample of Individuals with Severe Physical Disabilities}

\begin{tabular}{|c|c|}
\hline Type of Barrier & Common Barriers \\
\hline $\begin{array}{l}\text { Architectural/ } \\
\text { Environmental }\end{array}$ & $\begin{array}{l}\text { - Some building interiors were not accessible (such as elevators), especially older build- } \\
\text { ings } \\
\text { - Some classroom interiors were not accessible (lecture halls where seating was at front } \\
\text { or back) } \\
\text { - Some building exteriors (such as ramps and entrances) were not accessible or were } \\
\text { hidden } \\
\text { - Travel pathways, such as sidewalks and curb cuts were sometimes broken or steep, } \\
\text { especially in winter with ice and snow } \\
\text { - Size of campus (559 total buildings; } 7.7 \text { square miles; 4,938 acres) made travel be- } \\
\text { tween classes difficult }\end{array}$ \\
\hline Attitudinal & 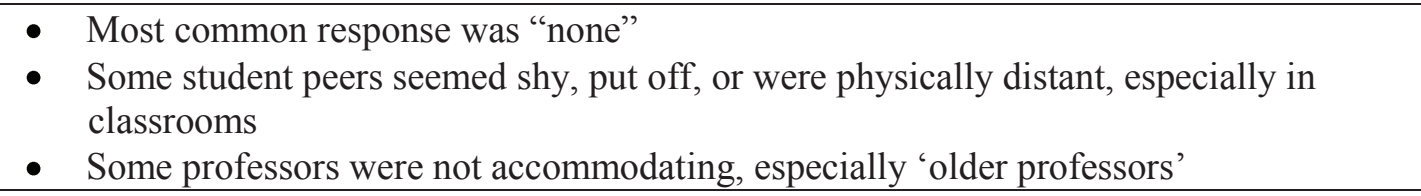 \\
\hline $\begin{array}{l}\text { Programmatic/ } \\
\text { Policies }\end{array}$ & 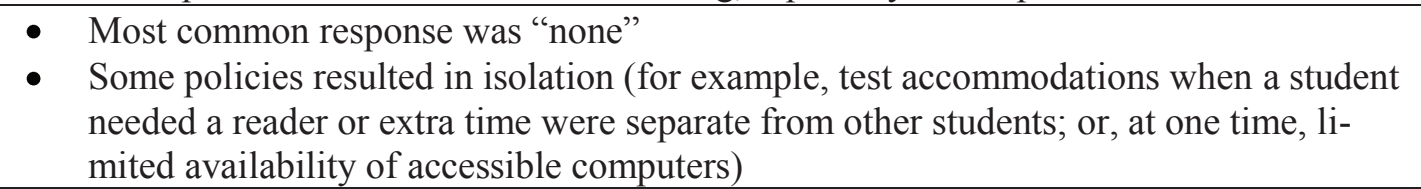 \\
\hline Financial & $\begin{array}{l}\text { - Most common response was "none" } \\
\text { - Most reported receiving funding from state departments of rehabilitation and did not } \\
\text { note further financial problems }\end{array}$ \\
\hline $\begin{array}{l}\text { Social/ } \\
\text { Communication }\end{array}$ & $\begin{array}{l}\text { Most reported isolation from peers as a result of architectural barriers, for example, } \\
\text { lack of accessibility at large lecture halls, fraternities, sororities, friends' apartments, } \\
\text { or restaurants } \\
\text { - Some students reported others' difficulties socially relating to someone with a disabil- } \\
\text { ity and using a power wheelchair } \\
\text { - Some reported difficulties with their own feelings of being a burden or being seen as } \\
\text { being different due to their disability } \\
\text { - Some students reported that the residence hall was isolative, in that it primarily } \\
\text { housed individuals with personal assistance needs }\end{array}$ \\
\hline Health & $\begin{array}{l}\text { - Most reported no health barriers } \\
\text { - Some noted that that they had learned to manage their disability's effect on their } \\
\text { health (for example, periodic weakness, secondary conditions) } \\
\text { - Some noted that faculty and health care providers needed to be made more aware of } \\
\text { health issues related to disabilities }\end{array}$ \\
\hline
\end{tabular}


Architectural barriers in work environments were commonplace for the alumni with severe disabilities. Attitudinal barriers in the workplace were mixed; some not reporting any barriers, some reported them in locating employment, and some reporting barriers during the interviewing process. Most individuals reported no workplace programmatic or policy barriers, and those who noted such barriers were often accommodated. Most participants reported no financial barriers in their careers, although some mentioned the high cost of living with a disability. Social and communication barriers in the workplace were more prevalent than those in the educational setting. Inaccessibility of facilities played a role in social and communication barriers in both educational and work settings. Most people in this study reported no health-related career barriers, although selfmanagement of their disability became an important factor. Table 2 displays a summary of the responses regarding career barriers.

\section{Table 2. Career Barriers for Sample of Individuals with Severe Physical Disabilities}

\begin{tabular}{|c|c|}
\hline $\begin{array}{l}\text { Architectural/ } \\
\text { Environmental }\end{array}$ & $\begin{array}{l}\text { - Most individuals experienced significant architectural and environmental barriers in } \\
\text { the workplace (such as entrances, washrooms, and work spaces) } \\
\text { - Some individuals also reported problems with public transportation not being accessi- } \\
\text { ble and/or available }\end{array}$ \\
\hline Attitudinal & $\begin{array}{l}\text { - Some individuals had not experienced attitudinal problems in the workplace } \\
\text { - Some individuals reported difficulty finding a job } \\
\text { - Some individuals reported difficulties during the interview, from possible discrimina- } \\
\text { tion to feelings of discomfort and uneasiness }\end{array}$ \\
\hline $\begin{array}{l}\text { Programmatic/ } \\
\text { Policies }\end{array}$ & $\begin{array}{l}\text { - Most individuals reported no career programmatic/policy barriers } \\
\text { - Some reported particular work rules (such as a timed lunch or prohibition of space } \\
\text { heaters in the workplace) that were changed for the individual } \\
\text { - Some individuals reported problems finding/affording work personal assistants }\end{array}$ \\
\hline Financial & $\begin{array}{l}\text { - Some individuals reported no career financial barriers } \\
\text { - Some noted the high cost of disability-related expenses, such as accessible vans or } \\
\text { health care }\end{array}$ \\
\hline $\begin{array}{l}\text { Social/ } \\
\text { Communication }\end{array}$ & $\begin{array}{l}\text { - Some individuals reported no career social or communication barriers } \\
\text { - More career-related social or communication barriers were noted than educational so- } \\
\text { cial or communication/barriers. Individuals reported feeling disadvantaged due to } \\
\text { their disability, from communication difficulties to inaccessible social functions to } \\
\text { feeling 'different' }\end{array}$ \\
\hline Health & $\begin{array}{l}\text { - Some individuals reported no career health barriers } \\
\text { - Some individuals reported that recurring health concerns happened as they aged and } \\
\text { that managing their disability was important }\end{array}$ \\
\hline
\end{tabular}


Vol. 14, No. 1- Winter, 2010/2011

Journal of Science Education for Students with Disabilities

\section{Educational and Career Facilita- tors}

The second research question in this study was: What technological, educational, and vocational facilitators are perceived by persons with severe disabilities to be most beneficial? Again, the 13 respondents were asked about facilitators in six broad categories.

The accessibility of the campus, the services of DRES, the availability of transitional residential personal assistance support services such as those provided through Beckwith Hall, and the availability of accessible campus and public transportation were seen as architectural and environmental facilitators during the participants' educational experiences. Overall, alumni stated that the positive and helpful attitudes of faculty, teaching, and administrative staff were important to their educational lives. Assistance from the state department of vocational rehabilitation was an important financial facilitator for many, as well their families' financial support. A number of students commented that having other students with severe physical disabilities in close proximity at Beckwith was an asset in that they could learn from one another and pass along useful tips and advice. Clubs and organizations, such as the Delta Sigma Omicron, the on-campus fraternity for students with disabilities, as well as broader interest organizations on campus were noted as important social enhancers. Health facilitators included the student health clinic, community healthcare providers and
DRES physical therapy staff. Table 3 provides a summary of educational facilitators as perceived by this sample of students with severe physical disabilities.

Individuals with severe physical disabilities in this sample reported fewer career facilitators in each category, and often, those enhancers mentioned were quite specific. Most enhancers discussed were in direct reply to a specific barrier, sometimes being resolved immediately (such as a raised desk) and some being resolved after considerable time (such as automatic doors being installed five years after the person was first employed). Participants in this sample indicated that the majority of architectural and environmental barriers that were first present when they became employed at a particular company or agency were no longer barriers. Attitudes in the workplace were not a problem. While some individuals mentioned that no programmatic or policies barriers existed so no remedies or facilitators were needed, many individuals remarked that the Americans with Disabilities Act (ADA) was an important career facilitator. Persons in this sample, in general, did not report major financial facilitators, although many mentioned that employers, state departments of vocational rehabilitation, medical insurance, and family members were important facilitators. Co-workers and supervisors were seen as social facilitators in the workplace. Health facilitators included work policies, medical insurance, and close proximity to healthcare providers. Table 4 provides data concerning career facilitators. 


\section{Table 3. Educational Facilitators for Sample of Individuals with Severe Physical Disabilities}

\begin{tabular}{|c|c|}
\hline $\begin{array}{l}\text { Architectural/ } \\
\text { Environmental }\end{array}$ & $\begin{array}{l}\text { - The vast majority of individuals found the university campus to be accessible, but often } \\
\text { required the intervention of the disability office to ensure access (for example, class- } \\
\text { rooms being changed or desks moved into classrooms) } \\
\text { - Some individuals stated that Beckwith Hall was an important educational facilitator } \\
\text { - Some individuals reported that accessibility of both the university and public transporta- } \\
\text { tion systems was an important facilitator }\end{array}$ \\
\hline Attitudinal & $\begin{array}{l}\text { - The majority of individuals noted that faculty, teaching assistants, administrators, and } \\
\text { advisors were educational facilitators } \\
\text { - Individuals reported that several faculty had come to Beckwith and tutored students } \\
\text { when weather made it difficult to be about; and DRES staff were repeatedly noted as } \\
\text { being helpful and supportive }\end{array}$ \\
\hline $\begin{array}{l}\text { Programmatic/ } \\
\text { Policies }\end{array}$ & $\begin{array}{l}\text { - The majority of individuals noted that DRES provided a number of educational facilita- } \\
\text { tors, such as an accessible bus service, PA training and provision, physical therapy, test } \\
\text { taking and the like } \\
\text { - Some individuals noted that personnel from the state vocational rehabilitation office } \\
\text { were facilitators } \\
\text { - Some individuals reported encountering no educational facilitators }\end{array}$ \\
\hline Financial & $\begin{array}{l}\text { - The vast majority of individuals noted that state assistance, such as that from state voca- } \\
\text { tional rehabilitation agencies, was a financial facilitator } \\
\text { - Some individuals also mentioned scholarships funded by DRES }\end{array}$ \\
\hline $\begin{array}{l}\text { Social/ } \\
\text { Communication }\end{array}$ & $\begin{array}{l}\text { - Most individuals noted that interacting with other Beckwith students and/or being in- } \\
\text { volved in Beckwith or DSO government was a facilitator } \\
\text { - Some individuals indicated that general university activities, clubs/organizations, and/or } \\
\text { study groups were social facilitators } \\
\text { - Some reported no social/communication facilitators during their university experience }\end{array}$ \\
\hline Health & $\begin{array}{l}\text { - Most individuals noted that health care professionals, such as medical doctors or nurses } \\
\text { either on-campus at the student health center or in local healthcare facilities were facili- } \\
\text { tators } \\
\text { - Some individuals noted that personal assistants and the physical therapists associated } \\
\text { - Sith DRES were facilitators } \\
\text { - Some individuals noted no educational facilitators for health }\end{array}$ \\
\hline
\end{tabular}

\section{Differences between STEM and Non-STEM}

The third and final research question was: How do the perceptions of these barriers and facilitators by alumni in STEM fields compare to those in non-STEM fields? This question is important since it has been re- ported that individuals with disabilities encounter significant barriers to entering and succeeding in STEM careers (Burgstahler, 1994; Cawley et al., 2002; National Science Foundation, 2004). This investigation intended to determine whether this was true for a select sample of individuals with severe physical disabilities. 
Vol. 14, No. 1- Winter, 2010/2011

Journal of Science Education for Students with Disabilities

\section{Table 4. Career Facilitators for Sample of Individuals with Severe Physical Disabilities}

\begin{tabular}{|c|c|}
\hline $\begin{array}{l}\text { Architectural/ } \\
\text { Environmental }\end{array}$ & $\begin{array}{l}\text { - Most individuals reported accessibility problems at work (such as inaccessible bathrooms } \\
\text { and doors), although the barriers were often remedied after the individual began working } \\
\text { there; problems were solved through both assistive technology and personal assistance } \\
\text { which often came from co-workers } \\
\text { - Many individuals reported no accessibility or environmental barriers at work }\end{array}$ \\
\hline Attitudinal & $\begin{array}{l}\text { - The vast majority of individuals reported no specific attitudinal facilitators at work, with } \\
\text { many reporting that co-workers were helpful and friendly }\end{array}$ \\
\hline $\begin{array}{l}\text { Programmatic/ } \\
\text { Policies }\end{array}$ & $\begin{array}{l}\text { - Most individuals reported no programmatic or policy facilitators during their career } \\
\text { - Many individuals reported that their places of employment had ADA (Americans with } \\
\text { Disabilities Act)-related policies in place that enhanced the accessibility of the work en- } \\
\text { vironment }\end{array}$ \\
\hline Financial & $\begin{array}{l}\text { - The vast majority of individuals reported no financial career facilitators } \\
\text { - Most individuals mentioned that assistive technology and work accommodations were } \\
\text { paid for by the workplace, by the department of rehabilitation services or by medical in- } \\
\text { surance } \\
\text { - Some individuals mentioned that their families were financial facilitators }\end{array}$ \\
\hline $\begin{array}{l}\text { Social/ } \\
\text { Communica- } \\
\text { tion }\end{array}$ & $\begin{array}{l}\text { - Most individuals indicated that their supervisors and co-workers were very supportive } \\
\text { and socially interactive, often helping the person at social functions } \\
\text { - Some individuals reported no social or communication career facilitators }\end{array}$ \\
\hline Health & $\begin{array}{l}\text { - Some individuals reported no health-related career facilitators } \\
\text { - Some individuals indicated that work-related policies, such as flex time and medical in- } \\
\text { surance coverage were important health facilitators } \\
\text { - A few individuals reported residing close to their health care providers as a career-related } \\
\text { health facilitator }\end{array}$ \\
\hline
\end{tabular}

\section{Differences in perceived barriers}

A number of differences were noted between the STEM and non-STEM alumni. STEM alumni were more likely to report architectural barriers on campus, while non-STEM alumni reported more social problems as a result of architectural barriers. While both groups reported few attitudinal problems on campus, non-STEM were more likely to report problems with teaching staff, fellow students, and co-residents of Beckwith Hall. There were no differences noted for programmatic and policy and financial barriers during their education. Even though both groups reported similar problems due to social and communication barriers, alumni with
STEM backgrounds reported feeling like they had imposed more on others for assistance. When differences of health barriers were observed, it was because individuals from non-STEM backgrounds reported more problems with healthcare providers and professors' policies than their STEM counterparts.

Alumni working in STEM-related fields were more likely to report architectural accessibility, attitudinal, and programmatic and policy, financial, and health problems in the workplace. Both groups were similar in reporting social and communication barriers. 


\section{Differences in perceived facilitators}

Both groups similarly identified that architectural and attitudinal enhancers included DRES, Beckwith Hall, and the general university campus. STEM alumni were more likely to report no programmatic and policy facilitators, while non-STEM graduates more frequently reported that DRES was a programmatic and policy facilitator. Both groups recognized the state assistance was a financial facilitator during their education. STEM students were more likely to report that Beckwith Hall and the
DSO were social contributors and that their health was positively affected by DRES physical therapy, functional training and strength and conditioning personnel, by personal assistants, and by their healthcare professionals.

STEM employees were more likely to mention specific instances of architectural, attitudinal, programmatic and policy, social and communication, and health facilitators. Non-STEM workers were more likely to report family as a financial facilitator. Table 5 provides this data.

\section{Table 5. Differences and Similarities between STEM and non-STEM Alumni with Regard to Perceived Barriers and Facilitators in Education and Careers}

\begin{tabular}{|c|c|}
\hline & of STEM and Non-STEM Alumni \\
\hline \multicolumn{2}{|l|}{ Educational Barriers } \\
\hline $\begin{array}{l}\text { Architectural/ } \\
\text { Environmental Bar- } \\
\text { riers }\end{array}$ & $\begin{array}{l}\text { - STEM alumni were much more likely to encounter architectural barriers during their education, } \\
\text { primarily due to the inaccessibility of older (science) campus buildings } \\
\text { - Non-STEM alumni were much more likely to report social problems resulting from inaccessi- } \\
\text { bility within educational environments }\end{array}$ \\
\hline Attitudinal & $\begin{array}{l}\text { - The majority of both STEM and non-STEM alumni reported no attitudinal problems during } \\
\text { their education } \\
\text { - Non-STEM individuals noted more attitudinal problems with faculty, others students in classes, } \\
\text { and other students at the residence hall }\end{array}$ \\
\hline $\begin{array}{l}\text { Programmatic/ } \\
\text { Policies }\end{array}$ & $\begin{array}{l}\text { - The majority of both STEM and non-STEM alumni reported no programmatic/policy problems } \\
\text { during their education } \\
\text { Both STEM and non-STEM individuals reported that the result of some programmatic policies, } \\
\text { such as taking exams at DRES and Beckwith Hall itself resulted in social isolation from peers } \\
\text { without disabilities }\end{array}$ \\
\hline Financial & $\begin{array}{l}\text { - Both STEM and non-STEM individuals reported similarly that state departments of vocational } \\
\text { rehabilitation precluded most financial barriers to education }\end{array}$ \\
\hline $\begin{array}{l}\text { Social/ } \\
\text { Communication }\end{array}$ & $\begin{array}{l}\text { Both STEM and non-STEM alumni reported similarly that social isolation, due to inaccessible } \\
\text { classrooms, social environments (such as fraternities and restaurants) and a separate residence } \\
\text { hall, was a barrier to their education } \\
\text { STEM alumni reported more frequently feeling that they felt they were an imposition on others } \\
\text { due to their disability }\end{array}$ \\
\hline Health & $\begin{array}{l}\text { - } \quad \text { Both STEM and non-STEM noted that their disability required self-management } \\
\text { - Non-STEM alumni were more likely to report problems with healthcare professionals and with } \\
\text { professors' unawareness and policy inflexibility to accommodate individuals with disabilities }\end{array}$ \\
\hline \multicolumn{2}{|l|}{ Career Barriers } \\
\hline $\begin{array}{l}\text { Architectural/ } \\
\text { Environmental }\end{array}$ & $\begin{array}{l}\text { - While both STEM and non-STEM individuals reported architectural barriers, STEM alumni } \\
\text { indicated more problems per workplace }\end{array}$ \\
\hline Attitudinal & $\begin{array}{l}\text { - } \begin{array}{l}\text { Both STEM and non-STEM individuals reported attitudinal barriers, but more STEM alumni } \\
\text { reported that attitudes became a problem during the job search and interviewing process }\end{array} \\
\end{array}$ \\
\hline
\end{tabular}


Vol. 14, No. 1- Winter, 2010/2011

Journal of Science Education for Students with Disabilities

\begin{tabular}{|c|c|}
\hline $\begin{array}{l}\text { Programmatic/ } \\
\text { Policies }\end{array}$ & $\begin{array}{l}\text { - The majority of both STEM and non-STEM alumni reported no programmatic/policy problems } \\
\text { during their career } \\
\text { STEM alumni listed more programmatic and policy barriers, for example, workplace produc- } \\
\text { tivity deadlines and state assistance policies that restricted payment for personal assistants to } \\
\text { those with less income }\end{array}$ \\
\hline Financial & $\begin{array}{l}\text { - About one-third of both groups reported no financial barriers during their career } \\
\text { - STEM graduates were more likely to report specific instances of high costs, such as paying for } \\
\text { accessible vans and medical bills }\end{array}$ \\
\hline $\begin{array}{l}\text { Social/ } \\
\text { Communication }\end{array}$ & $\begin{array}{l}\text { - Although about one-third of individuals from both STEM and non-STEM groups reported no } \\
\text { social or communication barriers at work, both STEM and non-STEM alumni noted patterns of } \\
\text { social exclusion at company events due to inaccessibility of the venue or the lack of accessible } \\
\text { transportation }\end{array}$ \\
\hline Health & $\begin{array}{l}\text { - Few individuals in either the STEM or non-STEM group had experienced health barriers related } \\
\text { to employment } \\
\text { - STEM graduates were more likely to report health problems }\end{array}$ \\
\hline \multicolumn{2}{|l|}{$\begin{array}{l}\text { Educational } \\
\text { Facilitators }\end{array}$} \\
\hline $\begin{array}{l}\text { Architectural/ } \\
\text { Environmental }\end{array}$ & $\begin{array}{l}\text { - Both groups overwhelmingly mentioned that DRES services (such as moving classes to access- } \\
\text { ible rooms and the accessible bus service), Beckwith Hall, and the general accessibility of cam- } \\
\text { pus were major educational facilitators }\end{array}$ \\
\hline Attitudinal & $\begin{array}{l}\text { - Individuals in both groups equally indicated that faculty and teaching assistants were accommo- } \\
\text { dating; some faculty physically coming to Beckwith Hall to tutor students when weather pre- } \\
\text { vented their traveling to class } \\
\text { Similarly, an equal number of students in STEM and non-STEM groups mentioned that DRES } \\
\text { staff removed many barriers so that the students became more integrated on campus }\end{array}$ \\
\hline $\begin{array}{l}\text { Programmatic/ } \\
\text { Policies }\end{array}$ & $\begin{array}{l}\text { - } \quad \text { STEM alumni were more likely to report no educational programmatic or policy facilitators } \\
\text { - Non-STEM graduates were more likely to indicate that DRES was an educational program or } \\
\text { policy facilitator }\end{array}$ \\
\hline Financial & $\begin{array}{l}\text { - Both groups reported that state assistance (for example, the state department of rehabilitation } \\
\text { services) was the primary financial facilitator during their education }\end{array}$ \\
\hline $\begin{array}{l}\text { Social/ } \\
\text { Communication }\end{array}$ & $\begin{array}{l}\text { - STEM graduates were more likely to mention Beckwith Hall and its residents as well as the } \\
\text { DRES-sponsored disabled students' organization as being social facilitators }\end{array}$ \\
\hline Health & $\begin{array}{l}\text { - } \quad \text { STEM graduates were more likely to report that DRES-sponsored physical therapy, personal } \\
\text { assistants, and university health services as being health facilitators }\end{array}$ \\
\hline \multicolumn{2}{|c|}{ Career Facilitators } \\
\hline $\begin{array}{l}\text { Architectural/ } \\
\text { Environmental }\end{array}$ & $\begin{array}{l}\text { - STEM alumni were more likely to report specific accommodations made in the workplace, such } \\
\text { as grab bars in bathrooms, nearby parking spaces, and signature stamps } \\
\text { - } \quad \text { Non-STEM alumni were more likely to report no accessibility barriers in the workplace }\end{array}$ \\
\hline Attitudinal & $\begin{array}{l}\text { - Although both groups noted co-workers and supervisors as positive, STEM graduates were } \\
\text { more likely to report no attitudinal facilitators in the workplace }\end{array}$ \\
\hline $\begin{array}{l}\text { Programmatic/ } \\
\text { Policies }\end{array}$ & $\begin{array}{l}\text { - Both groups were equally likely to report no programmatic or policy facilitators in their } \\
\text { workplace } \\
\text { STEM graduates were more likely to report specific instances of programmatic facilitators, such } \\
\text { as the ADA }\end{array}$ \\
\hline Financial & $\begin{array}{l}\text { - Both groups reported help with paying for accommodations, although the non-STEM group was } \\
\text { more likely to report financial help from family }\end{array}$ \\
\hline $\begin{array}{l}\text { Social/ } \\
\text { Communication }\end{array}$ & $\begin{array}{l}\text { - STEM graduates reported more frequently that co-workers and supervisors were important so- } \\
\text { cial facilitators in the workplace }\end{array}$ \\
\hline Health & $\begin{array}{l}\text { - STEM graduates were more likely to report workplace health insurance as a health facilitator in } \\
\text { the workplace }\end{array}$ \\
\hline
\end{tabular}




\section{DISCUSSION AND CONLCUSIONS}

The first research question addressed by this study concerned the educational and career barriers that were experienced by individuals with severe physical disabilities. This sample most frequently reported social isolation as a barrier during their education. Sometimes this may have been due to architectural inaccessibility, accommodation policies, and attitudes of others on campus. However, surprisingly, this group of alumni did not report pervasive or consistent problems with architectural or environmental accessibility, attitudes of others, programs and/or policies, finances, or health while on campus. However, once they reached work settings, architectural and environmental barriers became more commonplace. Programs and policies were not seen as common barriers, and the respondents reported that policy accommodations were often made to meet their individual needs. Only some individuals in the sample reported experiencing attitudinal, financial, social, or health barriers.

The second research question of this study examined the educational and career facilitators that were experienced by this sample of persons with severe physical disabilities.

Respondents seemed to be in greater agreement about their educational facilitators. Respondents agreed on a number of educational supports that were important to their educational success. These included campus accessibility, positive attitudes of teaching and support staff, DRES services and policies, financial assistance from state rehabilitation agencies, other students involved with Beckwith or with DSO, and healthcare professionals on campus or in the local community. The most commonly mentioned ca- reer facilitators included the supportiveness of co-workers and supervisors, the resolution of accessibility problems, and workrelated health policies. However, the majority felt there were no attitudinal, programmatic or policy, or financial facilitators in the workplace.

In examining the differences between STEM and non-STEM alumni, it was found that STEM alumni reported more architectural barriers during their education and this is likely due to the fact that some buildings (such as one in which most mathematics classes are held) are older, have been retrofitted, and are less disability-friendly. While at the university, non-STEM alumni reported more social and communication barriers although STEM alumni reported feeling that they imposed on others. While in school, non-STEM alumni reported more health problems. In the workplace, STEM individuals experienced barriers more frequently than non-STEM alumni in the areas of architectural, attitudinal, programmatic/policy, financial, and health barriers. In terms of educational facilitators, both groups repeatedly, prominently, and nearly equally mentioned the disability-related services at the university, and to a lesser degree, faculty and teaching assistants. And lastly in terms of career facilitators, STEM alumni were much more likely to name specific facilitators, such as architectural accommodations, the Americans with Disabilities Act, and workplace health insurance.

\section{Limitations}

While the present study provides valuable insight into the academic and workplace experiences of individuals with severe physical disabilities and contributes to a fuller 
Vol. 14, No. 1- Winter, 2010/2011

Journal of Science Education for Students with Disabilities

understanding of the barriers and facilitators they experienced, some methodological limitations need to be acknowledged. The study's sample was purposefully delimited to 13 individuals who had lived at Beckwith Hall or in the Tanbrier facility on the University of Illinois campus. Both the sampling technique and the sample size may limit the ability to generalize these results to other students with severe physical disabilities who have graduated from other universities. In addition, the 30-year span of graduation years may confound the results; however, all consenting participants were used so that an adequate sample size could be obtained. Although the present study offers no evidence that these individuals are unique, it is likely that they represent a more financially well-off group due to the housing costs associated with Beckwith and the personal assistance services.

\section{Directions for Future Research}

This exploratory study set out to determine the perceived barriers and facilitators experienced by alumni with severe physical disabilities as they attended a postsecondary institution with considerable personal and academic supports, and as they entered the workforce. Additional studies replicating this methodology at other universities, both similar and dissimilar to the University of Illinois, and with other disability groups, such as those with less-severe disabilities or with mental illnesses, are warranted. For example, what specific environments or accommodations resulted in fewer barriers as perceived by individuals with specific disabilities? Which environments provided the best conditions for learning and achievement of goals? Studies also might address whether students who are at campuses with less comprehensive services, especially in the area of personal assistance, report similar barriers and facilitators. Do these alternative environments result in additional or different barriers and facilitators than those found in this study? Does the lack of provision of personal assistance services become more prominent than other services for this group of individuals? What are acceptable levels, if any, of residual barriers that individuals can experience and still succeed? Which facilitators are essential and which are additive but not minimally required? What are the long-term economic and social costs and gains in providing such services? In addition, longitudinal studies that query individuals annually or bi-annually may be able to capture more reliable reports than the retrospective method used in this study. If individuals could be queried closer to the actual lived experience, then results may become more reliable. Additionally, quantitative studies conducted with greater numbers of individuals may result in a greater ability to generalize the results to larger population groups. It may also be beneficial to categorize university majors more discreetly than STEM and non-STEM. As mentioned earlier, this distinction was due to the funding source of this project, but other categorizations of majors are clearly possible.

\section{Implications for Practice}

The results of this study provide important insight into the lived experience of individuals with severe physical disabilities as they navigate college and workplace barriers and facilitators. From a practitioner perspective, it is clear that collecting evidence about service-recipients' experiences is an important step in providing the best possible service (Madaus, 2006; Paul, 2000). Conducting research into student experiences is an im- 
portant addition to the postsecondary disability service delivery knowledge base. Although it is a preliminary study and further research is warranted, its data reveals the importance of gathering student-centered perspectives.

The second implication for service delivery from these results is that a large and multifaceted cadre of supports needs to be in place in order for students with severe physical disabilities to be effective and succeed in higher education and careers. Although this research did not attempt to discern which services were effective and which were not, the fact that the vast majority of these students graduated with at least a baccalaureate degree and successfully transitioned to the workplace is important. The barriers and facilitators they noted generally excluded PAS services as these were covered in the Illinois housing options. It is possible that at other universities the lack of these extensive personal assistance services may be a primary barrier that was not uncovered in this study of Illinois graduates.

It should also be noted that transitional programs that provide PAS support are not inexpensive and that the state financial support that is so frequently cited as a facilitator by this sample of alumni is diminishing. As Stumbo, Martin, and Hedrick (2009) concluded, for individuals with severe physical disabilities it is likely that the provision of personal assistance is a 'deal breaker' on whether one succeeds in higher education.

The final implication is that even under relatively ideal circumstances and with all of the disability supports in place, individuals with severe physical disabilities continued to face architectural and attitudinal barriers that resulted in their social isolation from peers. In the classroom, this might have been because the only open space to park a power wheelchair was apart from the seating of other students. In the workplace, this might have been company parties at inaccessible locations, such as co-workers' homes. Although there has been much positive movement in these areas, much remains to be done.

\section{SUMMARY}

This study retrospectively explored the barriers and facilitators experienced by a purposive sample of alumni with severe physical disabilities as they attended postsecondary education and entered the workforce. Thirteen individuals were interviewed and results were transferred in table format for comparative analysis. The results of this study highlight educational and career facilitators and educational and career barriers experienced by these individuals. Due to the funding source, differences and similarities between STEM and non-STEM majors were compared. Although there are methodological limitations to small-scale, qualitative studies, implications for future research and practice are drawn. This study shows that tapping into students' lived experiences both while on campus and post-graduation can be useful in illuminating the kinds of barriers and facilitators they have encountered and the kinds of additional supports that may be needed that might otherwise be unknown without this kind of research. 


\section{AUTHOR NOTES AND ACKNOWLEDGEMENTS}

The information contained in this publication is based upon work supported by the National Science Foundation under Grant No. 0533197. Any opinions, findings, and conclusions or recommendations expressed in this material are those of the author(s) and do not necessarily reflect the views of the National Science Foundation. We would also like to thank the individuals with disabilities who participated in this study.

\section{DECLARATION OF INTEREST}

The authors report no conflicts of interest. The authors alone are responsible for the content and writing of the paper.

\section{REFERENCES}

Agree, E. M., \& Freedman, V. A. (2003). A comparison of assistive technology and personal care in alleviating disability and unmet need. The Gerontologist, 43, 335-344.

Belch, H. A. (2004). Retention of students with disabilities. Journal of College Student Retention, 6(1), 3-22.

Boeije, H. (2002). A purposeful approach to the constant comparative method in the analysis of qualitative interviews. Quality \& Quantity, 36, 391-409.

Bolt, D. (2004). Disability and the rhetoric of inclusive higher education. Journal of Further \& Higher Education, 28(4), 353358.

Burgstahler, S. (1994). Increasing the representation of people with disabilities in science, engineering, and mathematics. Accessed at: www.washington.edu/doit/brochures/careers /representation.html

Cawley, J., Hayden, S., Cade, E., \& BakerKroczynski, S. (2002). Including students with disabilities into the general education science classroom. Exceptional Children, 68(4), 423-435.

Collins, K. D., Hedrick, B. N., \& Stumbo, N. J. (2006). Using comprehensive postsecondary transitional support services to enhance the health, independence, and employment success of persons with severe physical and/or psychiatric disabilities: The University of Illinois approach. Champaign, IL: Division of Disability Resources and Educational Services. Accessed at: http://www.disability.uiuc.edu/files/best_pra ctices_files/textonly/index.html

DePoy, E., \& Gitlin, L. N. (1998). Introduction to research: Understanding and applying multiple strategies $\left(2^{\text {nd }}\right.$ ed.). St. Louis: Mosby.

Desai, M. M., Lentzner, H. R., \& Weeks, J. D. (2001). Unmet need for personal assistance with activities of daily living among older adults. The Gerontologist, 41, 82-88.

Diab, M. E., \& Johnston, M. V. (2004). Relationships between level of disability and receipt of preventive health services. Archives of Physical Medicine and Rehabilitation, 85, 749-757.

Dowrick, P. W., Anderson, J., Heyer, K., \& Acosta, J. (2005). Postsecondary education across the USA: Experiences of adults with disabilities. Journal of Vocational Rehabilitation, 22, 41-47.

Gajar, A. (1998). Postsecondary education. In F. Rusch and J. Chadsey (Eds.), Beyond high school: Transition from school to work. Belmont, CA: Wadsworth. 
Glaser, B. G., \& Strauss, A. L. (1967). The discovery of grounded theory: Strategies for qualitative research. Chicago: Aldine.

Guralnik, J. M. (2006). Aspects of disability across the life span: Risk factors for disability in late life In M. J. Field, A. M. Jette, and L. Martin (Eds.), Workshop in America: A new look: Summary and background papers (pp. 157-165). Washington, D. C.: National Academies Press.

Hemmingsson, H., \& Borell, L. (2000). Accommodation needs and studentenvironment fit in upper secondary schools for students with severe physical disabilities. Canadian Journal of Occupational Therapy, 67(3), 162-172.

Hoenig, H., Taylor, D. H., \& Sloan, F. A. (2003). Does assistive technology substitute for personal assistance among the disabled elderly? American Journal of Public Health, 93, 330-337.

Horn, L., \& Berktold, J. (1999). Students with disabilities in post-secondary education: A profile of preparation, participation, and outcomes. Washington, D. C.: U. S. Department of Education, National Center for Educational Statistics.

Jans, L., \& Stoddard, S. (1999). Chartbook on women and disability in the United States: An InfoUse report. Washington, D. C.: U.S. National Institute of Disability and Rehabilitation Research.

Kaye, H. S., Chapman, S., Newcomer, R. J., $\&$ Harrington, C. (2006). The personal assistance workforce: Trends in supply and demand. Health Affairs, 25, 1113-1120.

Kennedy, J., LaPlante, M. P., \& Kaye, H. S. (1997). Need for assistance in the activities of daily living. Disability Statistics Abstract, $18,4 \mathrm{pp}$.
Kohler, M., Clarenbach, C. F., Boni, L., Brack, T., Russi, E.W., \& Bloch, K. E. (2005). Quality of life, physical disability, and respiratory impairment in Duchenne muscular dystrophy. American Journal of Respiratory Critical Care and Medicine, 172, 1032-1036.

LaPlante, M. P., Kaye, H. S., Kang, T., Harrington, C. (2004). Unmet need for personal assistance services: Estimating the shortfall in hours of help and adverse consequences. Journals of Gerontology, 59B, S98-S108.

Lunsford, S. K., \& Bargerhuff, M. E. (2006). A project to make the laboratory more accessible to students with disabilities. Journal of Chemical Education, 83(3), 407409.

MacDonald, C., \& Stratta, E. (2001). From access to widening participation: Responses to the changing population in higher education in the UK. Journal of Further and Higher Education, 25(2), 249-258.

MacMillan, J. H., \& Schumacher, S. (2001). Research in education: A conceptual foundation ( $5^{\text {th }}$ ed.). New York: Longman.

Madaus, J. W. (2006). Employment outcomes of university graduates with learning disabilities. Learning Disability Quarterly, 29(1), 19-31.

Milsom, A. (2006). Creating positive school experiences for students with disabilities. Professional School Counseling, 10, 66-72.

National Center for the Study of Postsecondary Education Supports. (2000). Research findings brief: Topic review: Postsecondary education and employment, 4, 2 pp.

National Organization on Disability/Harris. (2004). N.O.D./Harris Survey of Americans with disabilities. New York: Author. 
Vol. 14, No. 1- Winter, 2010/2011

Journal of Science Education for Students with Disabilities

National Science Foundation. (2004). Women, minorities, and persons with disabilities in science and engineering. Accessed at: http://www.nsf.gov/statistics/showpub.cfm?T opID $=2 \&$ SubID $=7$

National Science Foundation. (2006). Demographic characteristics of employed scientists and engineers, by disability status and sex: 2003. Accessed at: http://www.nsf.gov/ statistics/wmpd/pdf/tabh-38.pdf

Parker, D. R., Shaw, S. F., \& McGuire, J. M. (2003). Program evaluation for postsecondary disability services. Journal of Developmental Education, 27(1), 1-6.

Paul, S. (2000). Students with disabilities in higher education: A review of the literature. College Student Journal, 34, 200-210.

Philip, I., Armstrong, G. K., Coyle, G. G., Chadwick, I., \& Machado, A. B. C. (1998). A better way to measure disability in older people. Age and Ageing, 27, 519-522.

Rao, S. (2004). Faculty attitudes and students with disabilities in higher education: A literature review. College Student Journal, 38(2), 191-198.

Sanderson, A. (2001). Disabled students in transition: A tale of two sectors' failure to communicate. Journal of Further and Higher Education, 25(2), 227-240.

Schutz, P. F. (2002). Transition from secondary to postsecondary education for students with disabilities: An exploration of the phenomenon. Journal of College Reading \& Learning, 33, 46-61.

Shaw, S. F., \& Dukes, L. L., III. (2005). Performance indicators for postsecondary disability services. Journal of Developmental Education, 29(2), 10-19.

Steinmetz, E. (2006). Americans with disabilities 2002, Current population Reports. Washington, D. C.: U. S. Census Bureau.
Stodden, R. A., \& Conway, M. A. (2003). Supporting individuals with disabilities in postsecondary education. American Rehabilitation, 27(1), 24-33.

Stodden, R. A., \& Dowrick, P. W. (1999). Postsecondary education and employment of adults with disabilities. American Rehabilitation, 25(3), 19-23.

Stodden, R., Whelley, T., Chang, C., \& Harding, T. (2001). Current status of educational support provision to students with disabilities in postsecondary education. Journal of Vocational Rehabilitation, 16, 189-198.

Stumbo, N. J., Martin, J. K., \& Hedrick, B. N. (2009). Personal assistance for students with severe physical disabilities in postsecondary education: Is it the deal breaker? Journal of Vocational Rehabilitation, 30, 11-20.

Tindal, G., Heath, B., Hollenbeck, K., Almond, P., \& Harris, M. (1998). Accommodating students with disabilities on largescale tests: An experimental study. Exceptional Children, 64, 439-450.

Unger, K. (1994). Access to educational programs and its effect on employability. Psychosocial Rehabilitation Journal, 17(3), 117-126.

United States Bureau of the Census. (1997). Disabilities affect one-fifth of all Americans: Proportion could increase in coming decades. Accessed at: www.census.gov/prod/3/97pubs/cenbr 975.pdf

United States Department of Education. (2005a). Auxiliary aids and services for postsecondary students with disabilities. Accessed at: www.ed.gov/about/offices/list/ocr/docs/auxa ids.html 
United States Department of Education. (2005b). Students with disabilities making great strides, new study finds. Accessed at: http://www.ed.gov/news/pressreleases/2005/ 07/07282005.html

Verbrugge, L. M., Yang, L., \& Juarez, L. (2004). Severity, timing, and structure of disability. Social and Preventive Medicine, 49, 110-121.

Waldrop, J., \& Stern, S. M. (2003). Disability status: 2000 - Census 2000 brief. Washington, D. C.: U. S. Census Bureau.
Waller, R., Mahmood, T., Gandi, R., Delves, S., Humphrys, N., \& Smith, D. (2005). Student mental health: How can psychiatrists better support the work of university medical centers and university counseling services? British Journal of Guidance \& Counseling, 33(1), 117-128.

Weisgerber, R. A. (1994). Successful science for students with disabilities. College Teaching, 42(2), 55-56.

\section{AUTHOR INFO}

\section{Norma J. Stumbo}

Midwest Alliance in Science, Technology, Engineering, and Mathematics (Midwest) nstumbo@illinois.edu

\section{Bradley N. Hedrick}

Director, Disability Resources and Educational Services

Coordinator, Severe Physical Disability, Midwest Alliance

University of Illinois

\section{Courtney Weisman}

Former Graduate Student, University of Wisconsin-Madison

Doctoral Student, Disability Studies, University of Illinois at Chicago

\section{Jay K. Martin}

Midwest Alliance in Science, Technology, Engineering, and Mathematics (Midwest) 